\title{
PENGARUH INTEGRITAS, KOMPETENSI, DAN PROFESIONALISME TERHADAP PRODUKTIVITAS KERJA KARYAWAN BAGIAN AKUNTANSI PADA PT. BANK MANDIRI (PERSERO) TBK MANADO
}

\author{
Falentina K. G. Rani ${ }^{1}$, Linda Lambey ${ }^{2}$ Sherly Pinatik ${ }^{3}$ \\ ${ }^{1,2,3}$ Jurusan Akuntansi, Fakultas Ekonomi dan Bisnis, Universitas Sam Ratulangi, Jl. Kampus Bahu, Manado, \\ 95115, Indonesia \\ E-mail : grace_rani13@yahoo.com
}

\begin{abstract}
The succeed of company is determined by the existing of human resources. Furthermore, high qualified competences and professionalism of human resources can improve work productivity. This research is aimed to know the influence of integrity, competences, and professionalism to accounting employees' productivity at PT. Bank Mandiri (Persero) Tbk Manado. This is a quantitative causal research. Data were collected by questionnaires and interviews. This study employed 36 respondents. Data were analysed by multiple linear regression analysis. Regression equation result is $Y=-13,193+0,590 X_{1}+$ $0,239 X_{2}+0,817 X_{3}+e$. Results show that integrity, competences, and professionalism influence employees' productivity.
\end{abstract}

Keywords: Integrity, Competences, Professionalism, and Work Productivity.

\section{PENDAHULUAN}

Kelangsungan suatu organisasi atau perusahaan sangat ditentukan oleh sumber daya manusia yang ada, baik kualitas maupun kuantitasnya. Sumber daya manusia memegang peranan penting dalam pencapaian tujuan perusahaan. Berhasil tidaknya suatu usaha, sebagian besar ditentukan oleh perilaku-perilaku manusia yang melaksanakan pekerjaan. Ketika penempatan sumber daya manusia tidak sesuai dengan keahlian dan kemampuan yang dimilikinya, maka akan berpengaruh pada kinerja sumber daya manusia.

Becker et al dikutip dalam Kibtiyah (2016 : 96) mendefinisikan integritas sebagai suatu hal yang berkaitan dengan kepercayaan dan kejujuran seseorang. Integritas diharapakan menimbulkan tujuan bersama untuk mencapai hal yang dicita-citakan. Seperti dalam sebuah perusahaan, integritas sangat penting dimiliki.

Marwansyah (2012 : 52) mengemukakan bahwa kompetensi sumber daya manusia adalah perpaduan pengetahuan, keterampilan, sikap dan karakteristik pribadi lainnya yang diperlukan untuk mencapai keberhasilan dalam sebuah pekerjaan, yang bisa diukur dengan mengunakan standar yang telah disepakati, dan yang dapat ditingkatkan melalui pelatihan dan pengembangan.

Profesionalisme merupakan faktor yang sangat penting dalam suatu lembaga atau organisasi. Pegawai yang profesional akan memperlihatkan kemampuan dan keahliannya, sikap dan displin, minat dan semangat. Oleh karena itu, pegawai dituntut untuk memiliki kemampuan secara profesional dalam melaksanakan tugas-tugasnya sehingga produktivitas mereka meningkat.

Dalam kegiatan perbankan, faktor tenaga kerja (karyawan) mempunyai pengaruh besar karena tenaga kerjalah yang melaksanakan proses perbankan tersebut. Sasaran utama pengelolaan sumber daya manusia tersebut adalah menciptakan sistem pemberdayaan personel yang dapat menampilkan kinerja yang produktif. Produktivitas kerja menunjukkan tingkat pegawai dalam mencapai hasil (output) terutama dilihat dari sisi kuantitasnya. Tingkat produktivitas setiap pegawai bisa berbeda, karena tergantung pada tingkat kegigihan dalam menjalankan tugasnya. 
PT. Bank Mandiri (Persero) Tbk adalah bagian dari program restrukturisasi perbankan yang dilaksanakan oleh pemerintahan Indonesia. Dewasa ini, penyebab kegagalan dan keberhasilan seorang pegawai sebagai sumber daya manusia yang produktif bukan hanya ditentukan oleh faktor internal (pribadi) berupa tingkat kemampuan dan kemauan seseorang, tetapi juga faktor eksternal (lingkungan).

Di antara beberapa hal yang menjadikan peningkatan produktivitas kerja karyawan, peneliti menganggap integritas, kompetensi, dan profesionalisme memiliki konstribusi yang cukup besar terhadap keberhasilan suatu perusahaan. Berdasarkan pemikiran tersebut, maka timbul keinginan peneliti untuk mengkaji lebih dalam mengenai pengaruh integritas, kompetensi, dan profesionalisme terhadap produktivitas kerja karyawan bagian akuntansi dalam menghasilkan laporan keuangan, sehingga penelitian ini diberi judul "Pengaruh Integritas, Kompetensi, dan Profesionalisme Terhadap Produktivitas Kerja Karyawan Bagian Akuntansi Pada PT. Bank Mandiri (Persero) Tbk Manado".

Adapun tujuan yang ingin dicapai dalam penelitian ini yaitu:

1. Untuk mengetahui pengaruh integritas terhadap produktivitas kerja karyawan bagian akuntansi pada PT. Bank Mandiri (Persero) Tbk Manado.

2. Untuk mengetahui pengaruh kompetensi terhadap produktivitas kerja karyawan bagian akuntansi pada PT. Bank Mandiri (Persero) Tbk Manado.

3. Untuk mengetahui pengaruh profesionalisme terhadap produktivitas kerja karyawan bagian akuntansi pada PT. Bank Mandiri (Persero) Tbk Manado.

\section{TINJAUAN PUSTAKA}

\subsection{Lingkungan Akuntansi Keuangan}

Menurut Giri (2012 : 3), akuntansi dapat dipahami dari tiga sudut pandang, yaitu sebagai: (a) kegiatan jasa, (b) bidang studi, dan (c) proses atau kegiatan. Akuntansi keuangan (financial accounting) adalah proses yang berkulminasi pada penyiapan dan pengkomunikasian laporan keuangan suatu entitas untuk digunakan pihak internal dan eksternal (Giri, 2012 : 4). Keluaran utama akuntansi keuangan adalah laporan keuangan.

\subsection{Pelaporan Keuangan dan Laporan Keuangan}

Menurut Giri (2012 : 4), penyajian dan penyampaian keseluruhan informasi keuangan suatu entitas ekonomi kepada pihak-pihak yang berkepentingan dengan bisnis perusahaan disebut pelaporan keuangan. Pelaporan keuangan terdiri atas informasi dalam laporan keuangan dan informasi lain. Laporan keuangan terdiri dari neraca, laporan laba rugi, laporan perubahan modal, laporan arus kas, dan Catatan Atas Laporan Keuangan (CALK). Laporan keuangan merupakan alat pokok yang secara formal digunakan untuk menyampaikan informasi keuangan kepada pihak di luar perusahaan.

\subsection{Definisi dan Ruang Lingkup Akuntansi Keperilakuan}

Menurut Suartana (2010 : 1), akuntansi keperilakuan adalah bagian dari disiplin ilmu akuntansi yang mengkaji hubungan antara perilaku manusia dengan sistem akuntansi, serta dimensi keperilakuan dari organisasi di mana manusia dan sistem akuntansi tersebut berada serta diakui keberadaannya. Akuntansi keperilakuan sendiri berkonsentrasi pada keperilakuan orang yang terkait dengan informasi akuntansi dan segala permasalahannya.

\subsection{Integritas}

Menurut Zahra (2011 : 123), integritas adalah komitmen untuk melakukan segala sesuatu sesuai dengan prinsip yang benar dan etis, sesuai dengan nilai dan norma, dan ada konsistensi untuk tetap melakukan komitmen tersebut pada setiap situasi tanpa melihat adanya peluang atau paksaan untuk keluar dari prinsip.

\subsection{Kompetensi}

Kompetensi merupakan hal yang sangat penting guna mencapai tujuan perusahaan secara efektif dan efisien. Karyawan yang memiliki kompetensi tinggi akan mampu 
melaksanakan tugasnya dengan baik. Kompetensi menunjukkan karakteristik pengetahuan dan keterampilan yang dimiliki atau dibutuhkan oleh setiap individu yang menjadikan mereka mampu untuk melakukan tanggung jawab mereka secara efektif dan meningkatkan standar kualitas profesional dalam pekerjaan mereka. Spencer dan Spencer dikutip dalam Siswandy (2017 : 2882) menguraikan secara rinci masing-masing karakteristik kompetensi sebagai berikut, yaitu pengetahuan, keterampilan, serta konsep diri dan nilai-nilai.

\subsection{Profesionalisme}

Menurut Siagian dikutip dalam Sufari (2013 : 14), profesional adalah keandalan dan keahlian dalam pelaksanaan tugas sehingga terlaksana dengan mutu tinggi, waktu yang tepat, cermat dan dengan prosedur yang mudah dipahami dan diikuti oleh pelanggan. Profesionalisme adalah komitmen para profesional terhadap profesinya.

\subsection{Produktivitas Kerja}

Menurut Mar'ih (2016 : 117), dalam produktivitas kerja dapat kita kaji dari dua dimensi, yaitu dimensi individual dan dimensi organisasional. Pada dimensi individu, produktivitas berkaitan dengan karakteristik-karakteristik individu yang dapat terlihat ketika individu tersebut memiliki keinginan untuk meningkatkan kualitas kehidupannya. Sementara itu, dimensi organisasional mengkaji produktivitas dalam kaitannya antara input dan output. Dengan begitu, produktivitas tak hanya akan berkaitan dengan kuantitas, tetapi juga kualitas, efektivitas, dan efisiensi dalam meraih output yang sesuai dengan yang diharapkan sebelumnya. Produktivitas kerja karyawan merupakan salah satu ukuran organisasi untuk mencapai tujuannya.

\subsection{Hipotesis}

Hipotesis penelitian dikembangkan dari teori-teori dan penelitian terdahulu. Berikut tiga hipotesis yang terdapat dalam penelitian ini:

$\mathrm{H}_{1}$ : Integritas berpengaruh secara signifikan terhadap produktivitas kerja.

$\mathrm{H}_{2}$ : Kompetensi berpengaruh secara signifikan terhadap produktivitas kerja.

$\mathrm{H}_{3}$ : Profesionalisme berpengaruh secara signifikan terhadap produktivitas kerja.

\section{METODE PENELITIAN}

\subsection{Jenis dan Sumber Data}

Data yang digunakan dalam penelitian ini adalah data kualitatif, yaitu data skala likert yang nantinya akan diubah menjadi suatu ukuran data kuantitatif. Sumber data yang digunakan dalam penelitian ini adalah data primer. Data ini berupa wawancara dan pemberian kuesioner yang diedarkan kepada para karyawan bagian akuntansi dan keuangan PT. Bank Mandiri (Persero) Tbk Manado.

\subsection{Sampel dan Teknik Pengambilan Sampel}

Dalam penelitian ini, teknik sampling yang digunakan yaitu nonprobability sampling dengan teknik purposive sampling, di mana penulis menetapkan pertimbangan-pertimbangan atau kriteria-kriteria tertentu yang harus dipenuhi oleh sampel-sampel yang digunakan. Dalam penelitian ini yang menjadi sampel yaitu karyawan yang memenuhi kriteria tertentu. Adapun kriteria yang dijadikan sebagai sampel penelitian yaitu:

1. Karyawan bagian akuntansi dan keuangan PT. Bank Mandiri (Persero) Tbk Manado.

2. Karyawan yang telah bekerja lebih dari 1 tahun.

\subsection{Metode Analisis}

Metode analisis yang digunakan dalam penelitian ini, yaitu: uji kualitas data kuesioner dengan melakukan uji validitas dan uji realiabilitas. Selain itu, agar hasil perhitungan dapat diinterpretasikan secara akurat dilakukan uji asumsi klasik yang meliputi uji normalitas, uji multikolonieritas, dan uji heterokedastisitas. Terakhir, dilakukan pengujian terhadap model regresi linear berganda yang meliputi uji koefisien determinasi $\left(\mathrm{R}^{2}\right)$ dan uji hipotesis secara parsial (uji t). Semua uji ini dilakukan dengan bantuan software SPSS Statistic versi 20. 


\section{HASIL ANALISIS DAN PEMBAHASAN \\ 4.1 Hasil analisis \\ 4.1.1 Uji Kualitas Data}

Uji Kualitas data dilakukan untuk melihat apakah data kuesioner yang diperoleh telah valid dan reliabel atau tidak.

a. Uji Validitas

Hasil pengujian validitas atas variabel integritas $\left(\mathrm{X}_{1}\right)$, kompetensi $\left(\mathrm{X}_{2}\right)$, profesionalisme $\left(\mathrm{X}_{3}\right)$, dan produktivitas kerja (Y) disajikan dalam tabel berikut:

\begin{tabular}{|c|c|c|c|}
\hline $\begin{array}{c}\text { Nomor Butir } \\
\text { Instrumen }\end{array}$ & Pearson Correlation & Signifikansi & Keterangan \\
\hline 1. & 0,721 & 0,000 & Valid \\
\hline 2. & 0,573 & 0,000 & Valid \\
\hline 3. & 0,756 & 0,000 & Valid \\
\hline 4. & 0,620 & 0,000 & Valid \\
\hline 5. & 0,753 & 0,000 & Valid \\
\hline
\end{tabular}

Sumber : Output SPSS

Hasil uji validitas untuk variabel integritas menunjukkan bahwa semua butir instrumen dinyatakan valid karena nilai $r$ hitung $>$ nilai $r$ tabel $(0,329)$ pada taraf $5 \%$ sehingga dapat digunakan sebagai alat pengumpulan data.

\begin{tabular}{|c|c|c|c|}
\hline $\begin{array}{c}\text { Nomor Butir } \\
\text { Instrumen }\end{array}$ & Pearson Correlation & Signifikansi & Keterangan \\
\hline 1. & 0,669 & 0,000 & Valid \\
\hline 2. & 0,553 & 0,000 & Valid \\
\hline 3. & 0,533 & 0,001 & Valid \\
\hline 4. & 0,372 & 0,026 & Valid \\
\hline 5. & 0,488 & 0,003 & Valid \\
\hline 6. & 0,332 & 0,048 & Valid \\
\hline 7. & 0,493 & 0,002 & Valid \\
\hline 8. & 0,566 & 0,000 & Valid \\
\hline 9. & 0,423 & 0,010 & Valid \\
\hline 10. & 0,758 & 0,000 & Valid \\
\hline 11. & 0,622 & 0,000 & Valid \\
\hline 12. & 0,480 & 0,003 & Valid \\
\hline 13. & 0,616 & 0,000 & Valid \\
\hline 14. & 0,454 & 0,005 & Valid \\
\hline 15. & 0,713 & 0,000 & 0,003 \\
\hline 16. & 0,478 & & \\
\hline
\end{tabular}

Sumber : Output SPSS

Hasil uji validitas untuk variabel kompetensi menunjukkan bahwa semua butir instrumen dinyatakan valid karena nilai $r$ hitung > nilai $r$ tabel $(0,329)$ pada taraf $5 \%$ sehingga dapat digunakan sebagai alat pengumpulan data.

\begin{tabular}{|c|c|c|c|}
\hline $\begin{array}{c}\text { Nomor Butir } \\
\text { Instrumen }\end{array}$ & Pearson Correlation & Signifikansi & Keterangan \\
\hline 1. & 0,714 & 0,000 & Valid \\
\hline 2. & 0,527 & 0,001 & Valid \\
\hline 3. & 0,639 & 0,000 & Valid \\
\hline 4. & 0,675 & 0,000 & Valid \\
\hline 5. & 0,731 & 0,000 & Valid \\
\hline
\end{tabular}

Sumber : Output SPSS 
Hasil uji validitas untuk variabel profesionalisme menunjukkan bahwa semua butir instrumen dinyatakan valid karena nilai $r$ hitung $>$ nilai $r$ tabel $(0,329)$ pada taraf $5 \%$ sehingga dapat digunakan sebagai alat pengumpulan data

\begin{tabular}{|c|c|c|c|}
\hline $\begin{array}{c}\text { Nomor Butir } \\
\text { Instrumen }\end{array}$ & Pearson Correlation & Signifikansi & Keterangan \\
\hline 1. & 0,752 & 0,000 & Valid \\
\hline 2. & 0,658 & 0,000 & Valid \\
\hline 3. & 0,855 & 0,000 & Valid \\
\hline 4. & 0,759 & 0,000 & Valid \\
\hline 5. & 0,779 & 0,000 & Valid \\
\hline 6. & 0,760 & 0,000 & Valid \\
\hline 7. & 0,714 & 0,000 & Valid \\
\hline 8. & 0,667 & 0,000 & \\
\hline
\end{tabular}

Sumber : Output SPSS

Hasil uji validitas untuk variabel produktivitas kerja menunjukkan bahwa semua butir instrumen dinyatakan valid karena nilai $r$ hitung > nilai $r$ tabel $(0,329)$ pada taraf $5 \%$ sehingga dapat digunakan sebagai alat pengumpulan data.

b. Uji Reliabilitas

Hasil pengujian reliabilitas atas variabel integritas $\left(\mathrm{X}_{1}\right)$, kompetensi $\left(\mathrm{X}_{2}\right)$, profesionalisme $\left(\mathrm{X}_{3}\right)$, dan produktivitas kerja (Y) disajikan dalam tabel berikut:

\begin{tabular}{|c|c|c|c|c|}
\hline No. & Variabel & $\begin{array}{c}\text { Cronbach's } \\
\text { Alpha }\end{array}$ & $\begin{array}{c}\text { Nof } \\
\text { Items }\end{array}$ & Keterangan \\
\hline 1. & Integritas $\left(\mathrm{X}_{1}\right)$ & 0,721 & 5 & Reliabel \\
\hline 2. & Kompetensi $\left(\mathrm{X}_{2}\right)$ & 0,836 & 16 & Reliabel \\
\hline 3. & Profesionalisme $\left(\mathrm{X}_{3}\right)$ & 0,663 & 5 & Reliabel \\
\hline 4. & Produktivitas Kerja $(\mathrm{Y})$ & 0,884 & 8 & Reliabel \\
\hline
\end{tabular}

Sumber : Output SPSS

Tabel di atas menunjukkan bahwa nilai cronbach's alpha untuk variabel integritas sebesar 0,721, variabel kompetensi sebesar 0,836, variabel profesionalisme sebesar 0,663, dan variabel produktivitas kerja sebesar 0,884. Dengan demikian dapat disimpulkan bahwa instrumen penelitian ini reliabel karena memiliki cronbach's alpha $>0,60$.

\subsubsection{Uji Asumsi Klasik}

Sebelum melakukan pengujian analisis regresi linear berganda, data terlebih dahulu diuji dengan uji asumsi klasik sebagai syarat melakukan pengujian. Uji asumsi klasik yang digunakan, yaitu: uji normalitas, uji heteroskedatisitas, dan uji multikolinearitas. Berikut hasil uji asumsi klasik yang diperoleh:

a. Uji Normalitas

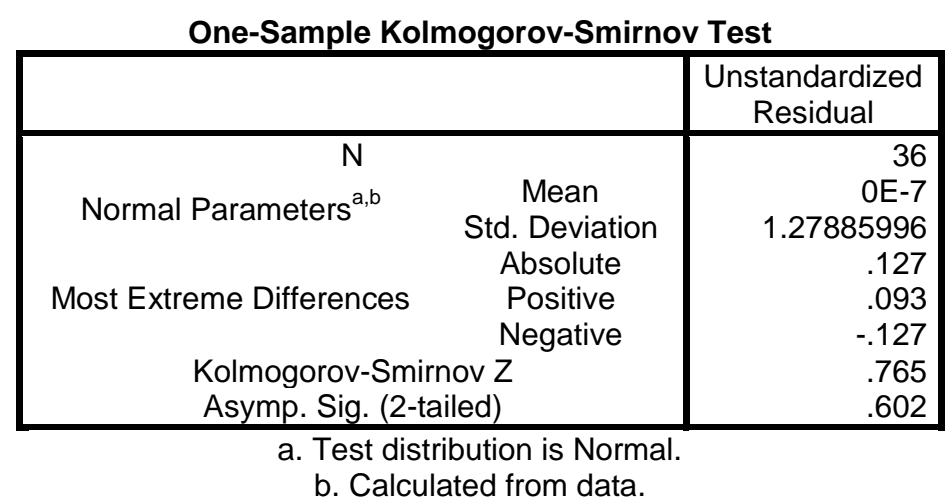

Sumber : Output SPSS 
Dapat dilihat bahwa nilai asymp. sig sebesar 0,602. Hal ini menunjukkan bahwa data berdistribusi normal karena nilai sig $>0,05$.

b. Uji Multikolinearitas

Pengujian multikolinearitas dalam penelitian ini dilakukan dengan melihat nilai tolerance dan Variance Inflation Factor (VIF). Apabila nilai tolerance $>0,10$ dan nilai VIF $<10$ maka dapat disimpulkan bahwa tidak ada multikolinearitas antar variabel independen dalam model regresi.

\begin{tabular}{|c|c|c|}
\hline \multirow{2}{*}{ Model } & \multicolumn{2}{|c|}{ Collinearity Statistics } \\
\cline { 2 - 3 } & Tolerance & VIF \\
\hline Integritas & 0,463 & 2,159 \\
\hline Kompetensi & 0,442 & 2,265 \\
\hline Profesionalisme & 0,361 & 2,766 \\
\hline
\end{tabular}

\section{Sumber : Output SPSS}

Dapat dilihat bahwa nilai tolerance untuk variabel integritas adalah 0,463, variabel kompetensi 0,442, dan variabel profesionalisme 0,361. Ketiga variabel ini memiliki nilai tolerance $>0,10$, maka dapat disimpulkan bahwa tidak ada multikolinearitas antar variabel independen dalam model regresi. Selain itu, dapat diliha jugat nilai VIF untuk variabel integritas adalah 2,159, variabel kompetensi 2,265, dan variabel profesionalisme 2,766. Ketiga variabel independen ini memiliki nilai VIF $<10$, sehingga dapat disimpulkan bahwa tidak ada multikolinearitas antar variabel independen dalam model regresi.

c. Uji Heteroskedastisitas

Berdasarkan tampilan scatterplot, dapat dilihat bahwa pola penyebaran titik-titik tidak jelas dan menyebar secara acak di atas maupun di bawah angka nol pada sumbu regression studentized residual. Hal ini menandakan bahwa tidak terjadi gejala heteroskedastisitas pada model regresi.

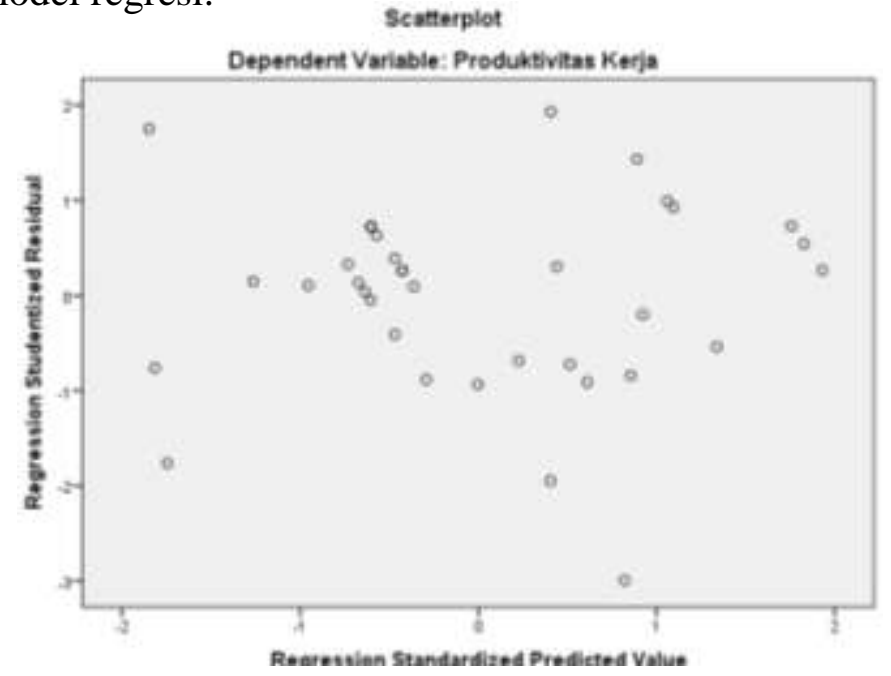

\subsubsection{Analisis Regresi Linear Berganda}

Sumber : Output SPSS

Berdasarkan hasil perhitungan dan pengolahan data dengan menggunakan bantuan program SPSS, diperoleh hasil perhitungan analisis regresi linear berganda sebagaimana diperlihatkan sebagai berikut: 
Coefficients $^{\mathrm{a}}$

\begin{tabular}{|c|r|r|r|r|r|}
\hline \multirow{2}{*}{ Model } & \multicolumn{2}{|c|}{ Unstandardized Coefficients } & \multicolumn{1}{c|}{$\begin{array}{c}\text { Standardized } \\
\text { Coefficients }\end{array}$} & \multirow{2}{*}{$\mathrm{t}$ Sig. } \\
\cline { 2 - 4 } & \multicolumn{1}{|c|}{$\mathrm{B}$} & Std. Error & \multicolumn{1}{c|}{ Beta } & \\
\hline & -13.193 & 3.241 & & -4.070 & .000 \\
(Constant) & .590 & .201 & .269 & 2.939 & .006 \\
Integritas & .239 & .066 & .340 & 3.629 & .001 \\
Kompetensi & .817 & .195 & .435 & 4.201 & .000 \\
\hline
\end{tabular}

a. Dependent Variable: Produktivitas Kerja

Sumber: Output SPSS

Berdasarkan data di atas, diperoleh persamaan regresi linear berganda sebagai berikut:

$$
\mathrm{Y}=-13,193+0,590 \mathrm{X}_{1}+0,239 \mathrm{X}_{2}+0,817 \mathrm{X}_{3}+\mathrm{e}
$$

1. Nilai konstanta $(\alpha)$ pada persamaan di atas adalah $-13,193$. Artinya, jika skor variabel integritas, kompetensi, dan profesionalisme dianggap konstan, maka produktivitas kerja karyawan akan menurun. Menurut Ralph dan Stone dikutip dalam Meylina dkk (2015), konstanta negatif tidak menjadi persoalan dan bisa diabaikan selama model regresi yang diuji sudah memenuhi asumsi (misal normalitas untuk regresi sederhana) dan selama slope (b) masih bernilai positif. Selain itu, konstanta negatif dapat terjadi jika rentang nilai antara $\mathrm{X}$ dan $\mathrm{Y}$ cukup jauh.

2. Nilai $\beta_{1}$ yang merupakan koefisien variabel integritas $\left(X_{1}\right)$ pada persamaan di atas sebesar 0,590 (positif). Hal ini berarti variabel integritas $\left(\mathrm{X}_{1}\right)$ berpengaruh positif atau searah terhadap variabel produktivitas kerja $(\mathrm{Y})$. Jika variabel integritas $\left(\mathrm{X}_{1}\right)$ meningkat, maka produktivitas kerja karyawan (Y) meningkat pula.

3. Nilai $\beta_{2}$ yang merupakan koefisien variabel kompetensi $\left(\mathrm{X}_{2}\right)$ pada persamaan di atas sebesar 0,239 (positif). Hal ini berarti variabel kompetensi $\left(\mathrm{X}_{2}\right)$ berpengaruh positif atau searah terhadap variabel produktivitas kerja $(\mathrm{Y})$. Jika variabel kompetensi $\left(\mathrm{X}_{2}\right)$ meningkat, maka produktivitas kerja karyawan (Y) meningkat pula.

4. Nilai $\beta_{3}$ yang merupakan koefisien variabel profesionalisme $\left(\mathrm{X}_{3}\right)$ pada persamaan di atas sebesar 0,817 (positif). Hal ini berarti variabel profesionalisme $\left(\mathrm{X}_{3}\right)$ berpengaruh positif atau searah terhadap variabel produktivitas kerja (Y). Jika variabel profesionalisme $\left(\mathrm{X}_{3}\right)$ meningkat, maka produktivitas kerja karyawan $(\mathrm{Y})$ meningkat pula.

\subsubsection{Koefisien Determinasi $\left(\mathbf{R}^{2}\right)$}

Berdasarkan pengujian yang dilakukan dengan menggunakan program SPSS, diperoleh hasil output sebagai berikut:

Model Summary

\begin{tabular}{|c|r|r|r|r|r|}
\hline Model & $\mathrm{R}$ & $\mathrm{R}$ Square & $\begin{array}{c}\text { Adjusted R } \\
\text { Square }\end{array}$ & $\begin{array}{c}\text { Std. Error of the } \\
\text { Estimate }\end{array}$ & Durbin-Watson \\
\hline 1 & $.936^{\mathrm{a}}$ & .876 & .864 & 1.337 & 1.398 \\
\hline
\end{tabular}

a. Predictors: (Constant), Profesionalisme, Integritas, Kompetensi

b. Dependent Variable: Produktivitas Kerja

\section{Sumber: Output SPSS}

Dapat dilihat bahwa nilai adjusted $\mathrm{R}^{2}$ adalah sebesar 0,864 atau $86,4 \%$, sehingga dapat disimpulkan bahwa variablel produktivitas kerja $(\mathrm{Y})$ mendapat kontribusi dari variabel integritas $\left(\mathrm{X}_{1}\right)$, kompetensi $\left(\mathrm{X}_{2}\right)$, dan profesionalisme $\left(\mathrm{X}_{3}\right)$ sebesar 0,864 atau $86,4 \%$, sedangkan sisanya sebesar $13,6 \%$ dijelaskan oleh faktor lain yang tidak dimasukkan dalam penelitian ini.

\subsubsection{Uji Hipotesis Secara Parsial (Uji t)}

Berdasarkan pengujian yang dilakukan dengan menggunakan program SPSS, diperoleh hasil output uji t sebagai berikut: 


\section{Coefficients $^{\mathrm{a}}$}

\begin{tabular}{|rc|r|r|r|r|r|}
\hline \multirow{2}{*}{ Model } & \multicolumn{2}{|c|}{$\begin{array}{c}\text { Unstandardized } \\
\text { Coefficients }\end{array}$} & $\begin{array}{c}\text { Standardized } \\
\text { Coefficients }\end{array}$ & \multicolumn{1}{c|}{$\mathrm{t}$ Sig. } \\
\cline { 3 - 5 } & \multicolumn{1}{|c|}{$\mathrm{B}$} & Std. Error & \multicolumn{1}{c|}{ Beta } & & \\
\hline \multirow{2}{*}{1} & (Constant) & -13.193 & 3.241 & & -4.070 & .000 \\
& Integritas & .590 & .201 & .269 & 2.939 & .006 \\
& Kompetensi & .239 & .066 & .340 & 3.629 & .001 \\
& Profesionalisme & .817 & .195 & .435 & 4.201 & .000 \\
\hline
\end{tabular}

a. Dependent Variable: Produktivitas Kerja

Sumber : Output SPSS

Uji t dilakukan dengan membandingkan nilai $t$ hitung dengan nilai $t$ tabel. Nilai $t$ hitung diperoleh dari perhitungan SPSS sedangkan $t$ tabel diperoleh dari tabel distribusi $t$ dicari pada $\alpha=5 \%: 2$ (uji 2 sisi) dengan derajat kebebasan (df) n-k-1 atau 36-3-1 = 32 . Dengan pengujian dua sisi (signifikansi $=0,025$ ), diperoleh hasil untuk t tabel sebesar 2,037, sehingga:

1. Jika t hitung > t tabel maka Ha diterima dan Ho ditolak.

2. Jika t hitung < t tabel Maka Ha ditolak dan Ho diterima.

Selain itu, untuk menguji apakah masing-masing variabel independen berpengaruh secara signifikan terhadap variabel dependen secara parsial dengan $\alpha=0,05$, maka cara yang dilakukan adalah:

1. Bila signifikansi $<0,05$ artinya variabel independen secara parsial mempengaruhi variabel dependen.

2. Bila signifikansi >0,05 artinya variabel independen secara parsial tidak mempengaruhi variabel dependen.

\subsection{Pembahasan}

Penelitian ini bertujuan untuk menguji pengaruh integritas, kompetensi, dan profesionalisme terhadap produktivitas kerja karyawan secara parsial. Berdasarkan pengujian hipotesis dengan menggunakan analisis regresi linear berganda, didapatkan hasil sebagai berikut:

a. Pengaruh integritas terhadap produktivitas kerja karyawan

Hasil penelitian menunjukkan bahwa nilai t hitung variabel integritas adalah 2,939, sehingga $t$ hitung 2,939 > t tabel 2,037 dan signifikansi variabel integritas sebesar 0,006, sehingga $0,006<0,05$. Hal ini menunjukkan bahwa variabel independen secara parsial mempengaruhi variabel dependen, sehingga terbukti bahwa integritas berpengaruh secara signifikan terhadap produktivitas kerja karyawan.

Integritas mewajibkan individu agar taat pada standar teknis dan etika yang dimiliki oleh organisasi. Integritas bukan hanya masalah kejujuran, masalah etis dan moral bahwa orang tidak berbohong atau tidak melakukan hal-hal tidak bermoral. Integrity berkaitan juga dengan kinerja, suatu pencapaian hasil baik yang dicapai dengan selalu menjunjung tinggi kejujuran dan nilai-nilai moral lainnya. Kata integrity berasal dari akar kata "integrated", yang berarti berbagai bagian dari karakter dan keterampilan berperan aktif dalam diri kita, yang tampak dari keputusan dan tindakan-tindakan kita (Atosokhi dikutip dalam Salwa, 2018). Untuk dapat menghasilkan kinerja yang baik di tempat kerja, seseorang harus memiliki sifat jujur, berani, berdaya juang, membangun hubungan baik, pandai mengorganisasikan diri sendiri, teratur, dan terencana dengan baik.

Hasil penelitian ini sesuai dengan penelitian terdahulu yang dilakukan oleh Prajitiasari (2010) dengan judul penelitian "Budaya Korporat dan Produktivitas Kerja Karyawan PT. Bank Rakyat Indonesia (Persero) Cabang Tulungagung”. Tujuan penelitian yang dilakukan oleh Prajitiasari (2010) adalah untuk menganalisis pengaruh budaya korporat yang terdiri atas variabel integritas, profesionalisme, kepuasan nasabah, keteladanan, dan penghargaan kepada sumber daya manusia terhadap produktivitas kerja karyawan baik secara simultan maupun 
parsial. Hasil penelitian menunjukkan bahwa variabel integritas memiliki angka signifikan di bawah 0,05. Sehingga, variabel integritas secara parsial berpengaruh signifikan terhadap produktivitas kerja karyawan.

b. Pengaruh kompetensi terhadap produktivitas kerja karyawan

Hasil penelitian menunjukkan bahwa nilai t hitung variabel kompetensi adalah 3,629, sehingga t hitung 3,629>t tabel 2,037 dan signifikansi variabel kompetensi sebesar 0,001, sehingga $0,001<0,05$. Hal ini menunjukkan bahwa variabel independen secara parsial mempengaruhi variabel dependen, sehingga terbukti bahwa kompetensi berpengaruh secara signifikan terhadap produktivitas kerja karyawan.

Menurut Serdamayanti dikutip dalam Mulyadi (2010 : 104), kompetensi kerja merupakan faktor kunci penentu bagi seseorang dalam menghasilkan kinerja yang sangat baik, sehingga dapat dikatakan bahwa kompetensi merupakan faktor penting yang dapat mempengaruhi produktivitas kerja karyawan. Apabila kinerja seseorang itu baik, maka akan menghasilkan produktivitas kerja yang baik pula. Hanon dikutip dalam Wasti (2017) mendefinisikan bahwa kompetensi merupakan suatu kemampuan seseorang dalam memanfaatkan atau menggunakan keterampilan serta ilmu pengetahuan yang ada padanya untuk dipergunakan dalam meningkatkan produktivitas kerja untuk pelaksanaan pekerjaan yang menjadi tanggung jawabnya. Kompetensi memiliki pengaruh pada produktivitas kerja dalam suatu negara atau instansi. Jadi, semakin tinggi kompetensi yang dimiliki seorang pegawai maka semakin besar produktivitas kerja yang diciptakan, dibandingkan dengan pegawai yang memiliki kompetensi yang rendah.

Hasil penelitian ini sesuai dengan penelitian terdahulu yang dilakukan oleh Siswandy (2017) dengan judul penelitian "Pengaruh Kompetensi terhadap Produktivitas Kerja Karyawan dengan Motivasi Sebagai Variabel Moderator di PT. PLN (Persero) Pusat Pemeliharaan Ketenagalistrikan Unit Workshop dan Pemeliharaan IV (PUSHARLIS UWP IV)". Tujuan penelitian yang dilakukan oleh Siswandy (2017) adalah untuk mengetahui pengaruh kompetensi terhadap produktivitas kerja dengan motivasi sebagai variabel moderator. Namun, Siswandy (2017) juga melakukan analisis regresi untuk melihat pengaruh antara kompetensi terhadap produktivitas kerja tanpa dipengaruhi oleh motivasi sebagai variabel moderator. Hasil penelitian menunjukkan bahwa kompetensi berpengaruh secara signifikan terhadap produktivitas kerja karyawan.

c. Pengaruh profesionalisme terhadap produktivitas kerja karyawan

Hasil penelitian menunjukkan bahwa nilai t hitung variabel profesionalisme adalah 4,201, sehingga t hitung 4,201 > t tabel 2,037 dan signifikansi dari variabel profesionalisme sebesar 0,000 , sehingga $0,000<0,05$. Hal ini menunjukkan bahwa variabel independen secara parsial mempengaruhi variabel dependen, sehingga terbukti bahwa profesionalisme berpengaruh secara signifikan terhadap produktivitas kerja karyawan.

Menurut Minarni (2017), profesionalisme adalah kemampuan dan keterampilan pegawai dalam melaksanakan proses dan prosedur pelaksanaan kegiatan kerja yang dipercayakan kepada seorang pegawai sesuai dengan bidang maupun tingkatan masingmasing, sehingga menciptakan hasil yang baik dan maksimal. Perilaku seorang profesional dapat dinilai dari keahlian dan pengetahuan yang luas dan bekerja dengan hati, memiliki kepercayaan yang tinggi, mampu bekerja efisien dan efektif, serta mampu untuk bekerja cerdas, cepat, cermat, dan tuntas.

Hasil penelitian ini sesuai dengan penelitian terdahulu yang dilakukan oleh Prajitiasari (2010) dengan judul penelitian "Budaya Korporat dan Produktivitas Kerja Karyawan PT. Bank Rakyat Indonesia (Persero) Cabang Tulungagung”. Tujuan penelitian yang dilakukan oleh Prajitiasari (2010) adalah untuk menganalisis pengaruh budaya korporat yang terdiri atas variabel integritas, profesionalisme, kepuasan nasabah, keteladanan, dan penghargaan kepada sumber daya manusia terhadap produktivitas kerja karyawan baik secara simultan maupun 
parsial. Hasil penelitian menunjukkan bahwa variabel profesionalisme memiliki angka signifikan di bawah 0,05 . Sehingga, variabel profesionalisme secara parsial berpengaruh signifikan terhadap produktivitas kerja karyawan.

\section{KESIMPULAN DAN SARAN}

5.1 Kesimpulan

1. Integritas berpengaruh terhadap produktivitas kerja karyawan bagian akuntansi pada PT. Bank Mandiri (Persero) Tbk Manado karena nilai t hitung 2,939 > t tabel 2,037 dan nilai signifikansi $0,006<0,05$.

2. Kompetensi berpengaruh terhadap produktivitas kerja karyawan bagian akuntansi pada PT. Bank Mandiri (Persero) Tbk Manado karena nilai t hitung 3,629>t tabel 2,037 dan nilai signifikansi 0,001 $<0,05$.

3. Profesionalisme berpengaruh terhadap produktivitas kerja karyawan bagian akuntansi pada PT. Bank Mandiri (Persero) Tbk Manado karena nilai t hitung 4,201 > $\mathrm{t}$ tabel 2,037 dan nilai signifikansi sebesar $0,000<0,05$.

\subsection{Saran}

1. Bagi perusahaan

Produktivitas kerja karyawan bagian akuntansi PT. Bank Mandiri (Persero) Tbk cabang Manado sudah termasuk dalam kategori baik. Oleh karena itu, pimpinan perusahaan perlu mempertahankan dan menciptakan suasana kerja yang mampu merangsang produktivitas kerja yang lebih tinggi lagi. Hal tersebut dapat dilakukan dengan cara memperhatikan faktor-faktor yang mempengaruhi produktivitas kerja karyawan sehingga tujuan perusahaan dapat tercapai.

2. Bagi peneliti selanjutnya

Peneliti menyarankan kepada para peneliti selanjutnya agar dapat menganalisis faktor-faktor lain yang berpengaruh terhadap produktivitas kerja karyawan, sehingga dapat memberikan kontribusi ilmiah yang baru terhadap topik penelitian ini.

\section{DAFTAR PUSTAKA}

Giri, E. F. 2012. Akuntansi Keuangan Menengah I : Perspektif IFRS. UPP STIM YKPN. Yogyakarta.

Kibtiyah, Asriana. 2016. Hubungan Integritas dan Loyalitas Karyawan dengan Visi Misi Perusahaan (Studi Kasus Pada PT. Bank Central Asia, Tbk). Jurnal Eduka. 2(2) : 92-110.

Mar'ih, Suci Rahayu. 2016. Mudah Menyusun Kualifikasi dan Performa Karyawan. Raih Asa Sukses. Jakarta.

Marwansyah. 2012. Manajemen Sumber Daya Manusia. Alfabeta. Bandung.

Meylina, E, dkk. 2015. Estimasi Tingkat Erosi pada Sistem Tumpangsari Kopi - Tanaman Semusim Menurut Metode MUSLE (Modified Universal Soil Loss Equation) di Desa Pace Kecamatan Silo Kabupaten Jember. Berkala Ilmiah Teknologi Pertanian 1(1) : 1-6.

Minarni, Elysa. 2017. Pengaruh Profesionalisme terhadap Produktivitas Kerja Pegawai pada Kantor Badan Pusat Statistik Kota Medan. Skripsi. Universitas Sumatera Utara. Medan.

Mulyadi, Hari. 2010. Pengaruh Motivasi dan Kompetensi Kerja terhadap Produktivitas Kerja Karyawan pada PT. Galamedia Bandung Perkasa. Jurnal Ilmu Administrasi dan Manajemen 9(17) : 97-111. 
Prajitiasari, E. D. 2010. Budaya Korporat dan Produktivitas Kerja Karyawan PT. Bank Rakyat Indonesia (Persero) Cabang Tulungagung. Wacana, Jurnal Sosial dan Humaniora 13(4) : 580-591.

Salwa, Arfah. 2018. Pengaruh Komitmen, Integritas, dan Kompetensi terhadap Kinerja Pegawai serta Dampaknya pada Kinerja Komisi Independen Pemilihan (KIP) Aceh. Jurnal Magister Manajemen Fakultas Ekonomi dan Bisnis Unsyiah 2(1) : 58-67.

Siswandy, A. 2017. Pengaruh Kompetensi terhadap Produktivitas Kerja Karyawan dengan Motivasi sebagai Variabel Moderator di PT. PLN (Persero) Pusat Pemeliharaan Ketenagalistrikan Unit Workshop dan Pemeliharaan IV (Pusharlis UWP IV). eProceeding of Management 4(3) : 2881-2887.

Suartana, I. W. 2010. Akuntansi Keperilakuan: Teori dan Implementasi. Andi. Yogyakarta.

Sufari, D. S. 2013. Pengaruh Profesionalisme Pemeriksa Pajak dan Komitmen Organisasi terhadap Kinerja Pegawai Pajak. Skripsi. Universitas Komputer Indonesia. Bandung.

Zahra, E. 2011. Pengaruh Integritas, Kompetensi dan Loyalitas Kepemimpinan terhadap Kepercayaan Para Bawahan di SBU Perkapalan PT. Pusri Palembang. Jurnal Ilmiah Orasi Bisnis. ISSN: 2085-1375. Edisi Ke-VI. Staf Pengajar Jurusan Administrasi Niaga. Politeknik Negeri Sriwijaya. 